\title{
Evaluation of Groundwater Suitability for Irrigation in the Lambussie-Karni District of Ghana*
}

\author{
${ }^{1}$ A. Asante-Annor, ${ }^{1}$ P. N. Bewil and ${ }^{2}$ D. Boateng \\ ${ }^{1}$ University of Mines and Technology, P.O. Box 237, Tarkwa, Ghana \\ ${ }^{2}$ Kumamoto University, Japan
}

Asante-Annor, A., Bewil, P.N. and Boateng, D. (2018), "Evaluation of Groundwater Suitability for Irrigation in the Lambussie-Karni District of Ghana", Ghana Mining Journal, Vol. 18, No. 1, pp. 9 - 19.

\begin{abstract}
The populace of the Lambussie-Karni District are mainly farmers who have resorted to the use of groundwater for irrigation during the dry season because of long drought and inadequate surface water bodies. The temporal variation of the groundwater quality for irrigation in the District was assessed using sixteen boreholes. Richard Plot indicates that groundwater in the study area is within the low salinity to low sodium hazard and medium salinity to low sodium hazard class. Wilcox Plot shows groundwater to be within excellent to good class in the catchment. Irrigation water quality index (IWQI) map was also developed to determine precisely the degree and areal extent of groundwater suitability for irrigation. ArcGIS 10.1 was used to generate thematic maps for sodium adsorption ratio (SAR), residual sodium carbonate (RSC), permeability index (PI), sodium percentage $(\mathrm{Na} \%), \mathrm{HCO}_{3}{ }^{-}, \mathrm{pH}$ and electrical conductivity. The results were compared to Food and Agricultural Organisations (FAO) standard guidelines. An IQWI map for the Lambussie- Karni District shows that groundwater is generally suitable for irrigation, about $24.57 \%$ of the district will require crops which can tolerate high amount of salts. A percentage (39.82\%) of the catchment has groundwater, which is highly suitable for crops which are least resistant to salt.
\end{abstract}

Keywords: Groundwater Suitability; Irrigation Water Quality; SAR; IWQI Map; Lambussie-Karni District

\section{Introduction}

The Lambussie-Karni District (LKD) is one of the major food Basket in the Upper West Region of Ghana. Over the period, the District has relied on rainfall for agriculture. In recent times, however, the District has been characterised by erratic rainfall pattern, high evapotranspiration and inadequate surface water bodies. These conditions impede all year-round farming resulting in food insecurity within the District. To remedy the situation, most of the farmers are resorting to the use of groundwater for irrigation during the dry season. The quality of groundwater for irrigation is critical for plant growth and the soil structural stability (Little et al., 2010).

Groundwater quality is generally assumed to be safe for consumption because it is located beneath the land surface and not typically in contact with the atmosphere (Quist et al., 1988). Its quality, however may be compromised by anthropogenic activities such as poor waste disposal and use of agrochemicals (Salifu et al., 2015). Naturally, groundwater quality can be influenced by the dissolution of minerals in rocks (Aghazadeh and Mogaddam, 2010). Irrigation water just as domestic water quality is dependent on the source of the water, flow path, geology and processes such as weathering, ion exchange, adsorption and dissolution

Additional source of water supply is required in addition to surface water bodies and rainwater; to achieve all year-round crop production in the study area. Groundwater has been identified as one alternative for irrigation farming. Because the quality of groundwater plays an important role in the sustainability of irrigation, this study seeks to evaluate the quality and suitability of groundwater for irrigational purposes in the Lambussie-Karni District of Ghana.

\subsection{Study Area}

The Lambussie-Karni District is located in the Upper West Region of Ghana. It lies between latitudes $10^{\circ} 25^{\prime \prime}$ and $11^{\circ} 00^{\prime \prime}$ North and longitudes $20^{\circ} 25^{\prime \prime}$ and $20^{\circ} 24^{\prime \prime}$ West (Fig.1). It covers a total land area of $811.9 \mathrm{~km}^{2}$ and about $92 \mathrm{~km}$ away from the regional capital Wa (Anon., 2014). The landscape is generally flat and low-lying with an average height of about $300 \mathrm{~m}$ above sea level. The vegetation is mainly of the Sahel Savannah type consisting of light undergrowth and scattered tress with fire swept grassland in the dry season separating deciduous trees (Dickson and Benneh, 1988).

The wet season commences from early April and ends in October. The dry season, which is characterised by the cold and hazy harmattan weather, starts from early November and ends in the latter part of March. The temperature of the District is generally between $15{ }^{\circ} \mathrm{C}$ low at night during the Harmattan season and a high of $40{ }^{\circ} \mathrm{C}$ in the day during the high temperature season (Anon., 2014). 


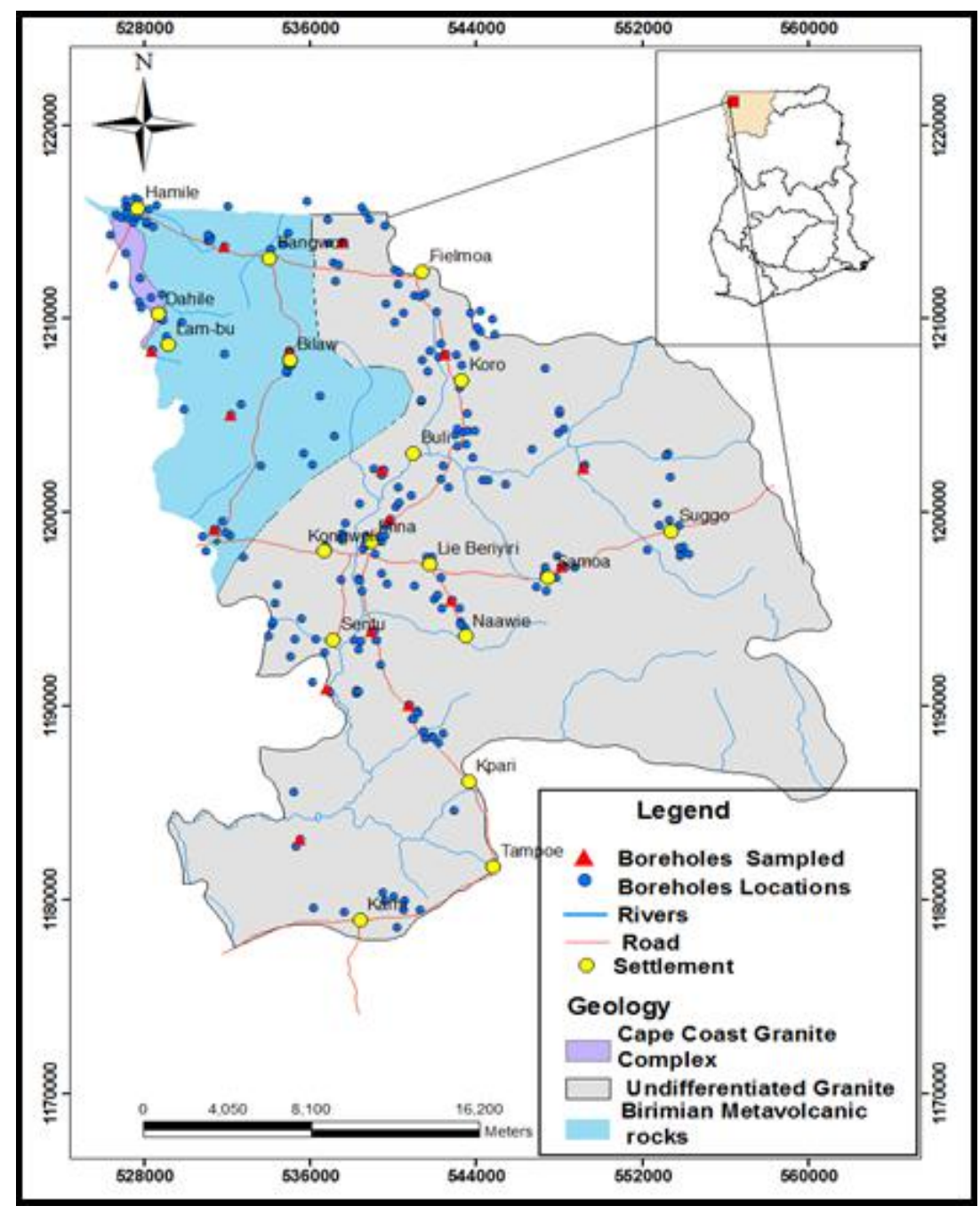

Fig.1 Geological Map and Sample Locations of Lambussie-Karni District (LKD) of Ghana

\subsection{Geology}

The Lambussie-Karni District (LKD) consists mainly of the Birimian metavolcanic rocks located in the north-western part and the rest occupied by granitoids. The Birimian metavolcanic rocks are dominantly made of metabasalts and metaandesites with volcanic and pyroclastic origin (Anku et al., 2009). They are mainly two (2) types of granitoids within the catchment which consist of the Dixcove type found with the metavolcanic rocks and the Cape Coast type at the contact of the Birimian Sedimentary rocks. According to Roudakov (1991), there is a gold mineralisation in the Lambussie, Bapala East and Hapa communities. They are mostly found in the narrow milky white quartz veins and streaks hosted in the Birimian metavolcaniclastics and the metasedimentary rocks. Extensive faults and fissure zones are found to be the most important structural features which control Birimian gold mineralisation (Dzigbodi-Adjimah, 1993).

\section{Resources and Methods Used}

\subsection{Sampling}

Two hundred and sixty-one (261) existing boreholes were identified and mapped in the Lambussie-Karni District; of which 16 boreholes (representing the 16 communities in the district) were sampled for physicochemical and irrigation water quality analysis. These boreholes were selected based on geology and its use for both irrigation and domestic purposes. Sampling protocols described by Barcelona et al. (1985) and Gale and Robins (1989) were strictly observed.

The boreholes were purged for a minimum of 12 minutes to pump out stagnant water in the PVC pipes before sampling and this was done during the dry season in May 2016. Plastic bottles were used for collecting samples. These bottles were thoroughly cleansed with detergent, rinsed with $\mathrm{HNO}_{3}$ and flushed with distilled water. Two separate samples were collected at each sample point for cations and anions analysis. The sample 
meant for cations analysis was immediately acidified to a $\mathrm{pH}<2$ using reagent grade nitric acid while those for anion analysis were without preservation. The collected samples were carefully sealed with proper labelling and preserved in ice between 0 and $4{ }^{\circ} \mathrm{C}$ throughout the holding time before analysis to reduce or stop chemical reactions and bacteria activity.

Field parameters were measured onsite whilst the chemical parameters were measured in the laboratory at Water Research Institute (WRI), Tamale within 24 hours of sampling. A Garmin GPSmap 60 CSx was used to pick the coordinates of the 261 sampling points. Ionic Balance Error (IBE) was computed to determine the neutrality or otherwise of the water and the accuracy of the laboratory results.

\subsection{Data Analysis}

The results of the physicochemical parameters were compared with the FAO standards. Mathematical computations were used to determine sodium percentage (Na \%), Sodium Adsorption Ratio (SAR), Residual Sodium Carbonate (RSC) and permeability Index (PI). Standard diagrams such as the Wilcox and U.S. Salinity diagram (Richard diagram) which shows graphical relationship between the electrical conductivity (EC) verses $\mathrm{Na} \%$ and EC verses SAR respectively were used. A correlation matrix was developed to establish the relationship between the physicochemical parameters using SPSS 16 software.

Irrigational water quality mapping was done using Inverse Distance Weighted (IDW) interpolation technique and classified into respective water quality classes. Ayers and Westcot (1985) list the hazards affecting irrigation water quality to include: (a) salinity hazard; (b) infiltration and permeability hazard; (c) specific ion toxicity hazard; (d) trace element toxicity hazard and; (e) hazard due to miscellaneous impacts on sensitive crops. A linear combination of these hazards forming an index, known as irrigation water quality index (IWQI) was used to assess the suitability of irrigation water (Jasmin and Mallikarjuna, 2015). The spatial maps of irrigation water quality parameters were used to develop an IWQI map for the district.

\subsubsection{Physicochemical Parameters}

Descriptive statistical analysis (mean, median, standard deviation, minimum and maximum ranges) was calculated using results of the physicochemical laboratory results. They include; $\mathrm{pH}$, Alkalinity, EC, TDS, $\mathrm{Ca}, \mathrm{Mg}, \mathrm{Na}, \mathrm{K}$ and $\mathrm{Cl}^{-}$,
$\mathrm{SO}_{4}{ }^{2-}, \mathrm{HCO}_{3}{ }^{-}$and $\mathrm{NO}_{3}{ }^{-}$. These results were compared with Food and Agriculture Organisation (FAO) guidelines as stated by Ayers and Westcott (1985).

\subsubsection{Irrigation Water Quality Calculated Parameters}

Mathematical computation of Sodium Adsorption Ratio (SAR), Sodium Percentage (Na \%), Residual Sodium Carbonate (RSC) and Permeability Index were estimated using the equations as shown in Table 1 . The results from the various calculations were compared with the minimum and maximum values for each of the methods as established by FAO standard guidelines.

\subsubsection{Standard Diagrams}

Standard diagrams such as Wilcox (1948) and Richard (1954) diagrams were used to assess the suitability of groundwater for irrigation. AquaChem 2012.1 was used to generate the Wilcox (1948) diagram by plotting the Sodium Adsorption Ratios (SAR) values against the corresponding EC values on a semi-log plot in accordance with the US Salinity Laboratory scheme. Richard diagram also known as US Salinity Laboratory scheme (USSL) was also drawn by plotting Sodium Percentage (Na \%) against Electrical Conductivity (EC) using Microsoft Excel. These diagrams usually determine the relationship among the salinisation, sodisation and the alkalinisation of the groundwater.

\subsubsection{Correlation Matrix}

Correlational analysis was carried out using results from the physicochemical parameters with SPSS 16 software. Correlation between parameters indicated by their correlation coefficients give the association between the parameters. Correlation coefficients of 0.5 and above indicates a strong positive association between parameters.

\subsection{Irrigation Water Quality Mapping}

Crop growth is affected by both irrigation water quality and drainage characteristics of the soil. The major water quality hazards affecting irrigation have been classified according to Simsek and Gunduz (2007) into five groups namely: Salinity hazards (electrical conductivity), infiltration and permeability hazards (SAR), specific ion toxicity $\left(\mathrm{Na} \%\right.$ and $\left.\mathrm{Cl}^{-}\right)$, trace element toxicity hazards $\left(\mathrm{F}^{-}\right)$ and miscellaneous effects $\left(\mathrm{pH}\right.$ and $\left.\mathrm{HCO}_{3}{ }^{-}\right)$. Mapping the spatial distribution of irrigation water quality was done using seven parameters namely; EC, SAR, RSC, $\mathrm{Na} \%, \mathrm{PI}, \mathrm{pH}$ and $\mathrm{HCO}_{3}{ }^{-}$. 


\subsubsection{Salinity Hazards}

Salinity hazards is a major component of irrigation water quality that affects crop growth and yields. This occurs when salts accumulate in the crop root zone reducing the amount of water available to the roots. Drastic reduction of available water to plant or crop results in reduction in crop yields. Ayers and Westcot (1989), states that when this water stress is prolonged, plant slows its growth and drought-like symptoms start to develop.

The source of salt in water could be from either anthropogenic or natural activities such as weathering of the rocks as the water percolate. Salinity hazard is generally measured by either electrical conductivity or the amount of total dissolved salts. In general, the amount of water available to the crop gets lower when the electrical conductivity is higher which leads to physiological drought and poor crop yield (Fipps, 2003).

\subsubsection{Permeability and Infiltration Hazard}

The infiltration of water into the soil is affected mainly by the soil condition such as the compaction of the soil, organic content and the soil permeability and the quality of the irrigation water. The permeability and infiltration hazards occur when high sodium ions decrease the rate at which irrigation water enters the soil's lower layers (Khalaf and Hassan, 2013). High reduction in permeability and infiltration rates results in negative impact such as the inadequate supply of water to the crop roots. According to Simsek and Gunduz (2007), when the crop is not able to extract the required amount of water from the soil, it is not possible to maintain an acceptable yield and the agricultural production is reduced. The SAR value of irrigation water is the key quality parameter that quantifies the relative proportions of sodium $\left(\mathrm{Na}^{+}\right)$ to calcium. Sodium Adsorption Ratio (SAR) was calculated using the Richards (1954) equation as shown in Table1.

\subsubsection{Specific Ion Toxicity}

Other ions considered in the analysis which equally have effect on the crops are mainly the sodium percent $(\mathrm{Na} \%)$ and chloride $\left(\mathrm{Cl}^{-}\right)$. The impact of sodium toxicity on plants are leaf burn, scorch and dead tissues whilst the toxicity of chloride results in leaf burn or tissue deaths (Simsek and Gunduz, 2007). Sodium percentage was calculated using the Wilcox (1955) equation as indicated in Table 1.

\subsubsection{Miscellaneous Effects}

The $\mathrm{pH}$, residual sodium carbonate (RSC) and the bicarbonate of the water were analysed to determine the electrical neutrality of the water. Generally, alkalinity measures the capacity of water to neutralise acid. The carbonate and bicarbonate are generally responsible for high $\mathrm{pH}$. High levels of carbonates cause calcium and magnesium ions to form insoluble minerals leaving sodium as the dominant ion in solution (Simsek and Gunduz, 2007).

\subsection{Irrigation Water Quality Index IWQI}

The irrigation water quality index (IWQI) model was derived from the linear combination of salinity hazard; infiltration and permeability hazard; specific ion toxicity hazard; trace element toxicity hazard and; hazard due to miscellaneous impacts on sensitive crops (Ayers and Westcot, 1985; Rokbani et al., 2011). Equation for the various hazards according to Jasmin and Mallikarjuna (2015) were formulated as follows:

Salinity Hazards index (G1)

$G_{1}=w_{1} r_{1}$

Infiltration and permeability hazard index (G2)

$G_{2}=w_{2} r_{2}$

Specific ion toxicity hazard index (G3)

$G_{3}=\frac{w_{3}}{n} \sum_{j=1}^{n} r_{j}$

Trace element toxicity hazard index (G4)

$G_{4}=w_{4} r_{4}$

Miscellaneous hazard index (G5)

$G_{5}=\frac{w_{5}}{n} \sum_{k=1}^{n} r_{k}$

The irrigation water quality index (IWQI) is generally expressed as

$I W Q I=\sum_{k=1}^{5} G_{k}$

where

Gk = Irrigation Water Hazard Index

$\mathrm{Wi}=$ Weight assigned to the hazard

$\mathrm{Ri}=$ rating 
Table 1 Calculated Irrigation Water Quality Parameters and Formulae

\begin{tabular}{|c|c|c|}
\hline Parameter & Formula & Reference \\
\hline Sodium Adsorption Ratio (SAR) & $\frac{N a^{+}}{\sqrt{\left(C a^{2+}+M g^{2+}\right) / 2}}$ & Richards (1954) \\
\hline $\begin{array}{l}\text { Sodium Percentage } \\
(\mathrm{Na} \%)\end{array}$ & $\frac{\left(N a^{+}+K^{+}\right) \times 100}{\left(C a^{2+}+M g^{2+}+N a^{+}+K^{+}\right)}$ & Wilcox (1955) \\
\hline $\begin{array}{l}\text { Residual sodium carbonate } \\
\text { (RSC) }\end{array}$ & $\left(\mathrm{HCO}_{3}^{-}+\mathrm{CO}_{3}^{2-}\right)-\left(\mathrm{Ca}^{2+}+\mathrm{Mg}^{2+}\right)$ & Eaton (1950); Richards (1954) \\
\hline Permeability Index (PI) & $\frac{N a^{+}+\sqrt{\left(\mathrm{HCO}_{3}^{-}\right)}}{N a^{+}+C a^{2+}+M g^{2+}} \times 100$ & Doneen (1964); Raghunath (1987) \\
\hline
\end{tabular}

Table 2 Irrigation Water Quality Classification

\begin{tabular}{|c|c|c|c|c|c|}
\hline \multirow[b]{3}{*}{ Irrigation Water Hazard } & \multirow[b]{3}{*}{ Weight } & \multirow[b]{3}{*}{ Parameter } & \multicolumn{3}{|c|}{ Suitability Rating (r) } \\
\hline & & & High & Medium & Low \\
\hline & & & 3 & 2 & 1 \\
\hline Salinity Hazard & 5 & $\mathrm{EC}$ & $<700$ & $700-3000$ & $>3000$ \\
\hline Permeability Hazard & 4 & $\begin{array}{l}\text { SAR 0-3 } \\
3-6 \\
6-12\end{array}$ & $\begin{array}{l}\mathrm{EC}>700 \\
\mathrm{EC}>1200 \\
\mathrm{EC}>1900\end{array}$ & $\begin{array}{l}700-200 \\
1200-300 \\
1900-500\end{array}$ & $\begin{array}{l}\mathrm{EC}<200 \\
\mathrm{EC}<300 \\
\mathrm{EC}<500\end{array}$ \\
\hline \multirow[t]{2}{*}{ Specific ion toxicity } & 3 & $\operatorname{SAR}\left(\mathrm{Na}^{+}\right)$ & $<3$ & $3-9$ & $>9$ \\
\hline & & $\mathrm{Cl}^{-}$ & $<140$ & $140-350$ & $>350$ \\
\hline Trace element toxicity & 2 & $\mathrm{~F}^{-}$ & $<1$ & $1-15$ & $>15$ \\
\hline \multirow[t]{2}{*}{ Miscellaneous effect } & 1 & $\mathrm{HCO}_{3}^{-}$ & $<90$ & $90-500$ & $>500$ \\
\hline & & $\mathrm{pH}$ & 7- 8 & $6.5-7$ and $8-8.5$ & $<6.5$ and $>8.5$ \\
\hline
\end{tabular}

Weights (1-5) were assigned to the individual water quality parameters according to the degree of the effect on the growth of the crop as shown in Table 2. The hazard groups were also assigned suitability rating 1,2, 3 for low, medium and high suitability of irrigation water respectively in Table 2. Simsek and Gunduz (2007) also classified IWQI into three (3) irrigation water suitability classes namely: low $(<22)$, medium $(22-37)$ and high $(>37)$.

\section{Results and Discussions}

The suitability of groundwater quality for irrigation in the study area was determined based on analysis of physicochemical parameters, deductions from standard diagrams, spatial distribution of irrigation water quality parameters and the IWQI Map.

\subsection{Results of Physicochemical Parameters}

The $\mathrm{pH}$ of groundwater in the study area ranges from 6.97 to 7.90 indicating that the water is neutral to moderately alkaline. TDS values ranges from 80.29 to $306 \mathrm{mg} / \mathrm{L}$ with a mean value of
$183.332 \mathrm{mg} / \mathrm{L}$. EC values ranges from 130 to 495 $\mu \mathrm{S} / \mathrm{cm}$ with a mean value of 296.438 .

The concentration of $\mathrm{Na}^{+}$in the groundwater ranges from 0.287 to $1.457 \mathrm{meq} / \mathrm{L}$ with a mean value of $0.63 \mathrm{meq} / \mathrm{L}$. $\mathrm{K}^{+}$had a mean value of 0.085 $\mathrm{meq} / \mathrm{L}$ and ranges from 0.023 to $0.156 \mathrm{meq} / \mathrm{L}$. The concentration of $\mathrm{Ca}^{2+}$ varies from 0.48 to 3.53 $\mathrm{meq} / \mathrm{L}$ and had average mean of $1.84 \mathrm{meq} / \mathrm{L}$ whilst $\mathrm{Mg}^{2+}$ ranges from 0.32 to $2.28 \mathrm{meq} / \mathrm{L}$ with a mean of $1.34 \mathrm{meq} / \mathrm{L}$. $\mathrm{Cl}^{-}$varies in concentration from 0.09 to $0.31 \mathrm{meq} / \mathrm{L}$ with a mean value of 0.20 meq/L. The concentration of $\mathrm{HCO}_{3}{ }^{-}$on the other hand varies from 1.44 to $5.92 \mathrm{meq} / \mathrm{L}$. The concentration of $\mathrm{SO}_{4}{ }^{2-}$ ranges from $0-0.381$ meq/L with a mean value of $0.068 \mathrm{meq} / \mathrm{L}$ whilst $\mathrm{SO}_{3}{ }^{2-}$ varies from $0-0.012 \mathrm{meq} / \mathrm{L}$. $\mathrm{NO}_{3}{ }^{-}$ranged from 0 to $0.11 \mathrm{meq} / \mathrm{L}$ with a mean value of 0.03 meq/L and $\mathrm{NO}_{2}^{-}$varies from 0 to $0.003 \mathrm{meq} / \mathrm{L}$ with a mean value of $0.001 \mathrm{meq} / \mathrm{L}$.

The mean concentration of the cations and anions (meq/L) in descending order are $\mathrm{Ca}^{2+}<\mathrm{Mg}^{2+}<\mathrm{Na}^{+}$ $<\mathrm{K}^{+}<\mathrm{NH}_{4}{ }^{+}$and $\mathrm{HCO}_{3}{ }^{-}<\mathrm{Cl}^{-}<\mathrm{SO}_{4}{ }^{2-}<\mathrm{SO}_{3}{ }^{2-}<$ $\mathrm{NO}_{3}{ }^{-}$respectively as shown in Table $3 . \mathrm{NH}_{4}{ }^{+}$was below the detectable limit of 0.001 except for the 
communities Hachangan $(0.028 \mathrm{mg} / \mathrm{L})$ and Kpare $(0.07 \mathrm{mg} / \mathrm{L})$. All the physicochemical parameters were within the usual range set by the FAO for irrigation water.

\subsection{Irrigation Water Quality Based on Deduction from Standard Diagrams}

Standard diagrams such as Wilcox (1955) and Richard (1954) were determined for the district to determine the suitability of the groundwater for irrigation.

\subsubsection{Wilcox Diagram}

The Wilcox plot in Fig. 2. shows that all the sample points were within the "Excellent to Good" category. The Wilcox plot relates sodium percentage to electrical conductivity (EC) as high amount of any is harmful to plant growth. From the plot, both $\mathrm{Na} \%$ and $\mathrm{EC}$ have low values and within the "Excellent to Good" category hence the quality of groundwater in the area with respect $\mathrm{Na} \%$ and $\mathrm{EC}$ is good for irrigation.

\subsubsection{Richard Diagram}

The analytical data of Sodium Adsorption Ratio (SAR) and conductivity plotted on the US salinity diagram as shown Fig. 3 indicate majority of the groundwater samples fell in the field of C1S1, representing low salinity and low sodium water. Hence, groundwater can be used for irrigation on all types of soils without danger of exchangeable sodium. Samples in the C2S1 field indicates good quality favourable for all crop types except the very salt sensitive crops.

\subsection{Correlation Matrix}

Correlation among the physicochemical water quality parameters was established using SPSS as shown in Table 4.

Table 3 Descriptive Statistics of Physicochemical Parameters

\begin{tabular}{|c|c|c|c|c|c|c|c|}
\hline Parameter & Units & Min & Max & Mean & Median & SD & $\begin{array}{c}\text { FAO } \\
\text { Standards }\end{array}$ \\
\hline Conductivity & $\mu \mathrm{S} / \mathrm{cm}$ & 130.00 & 495.00 & 296.44 & 278.00 & 133.87 & $0-3000$ \\
\hline pH & & 6.97 & 7.90 & 7.40 & 7.39 & 0.29 & $6-8.50$ \\
\hline TDS & $\mathrm{mg} / \mathrm{L}$ & 80.29 & 306.00 & 183.33 & 172.50 & 82.83 & $0-2000$ \\
\hline $\mathrm{NO}_{3}^{-}$ & $\mathrm{meq} / \mathrm{L}$ & 0.00 & 0.105 & 0.033 & 0.03 & 0.02 & $0-10$ \\
\hline $\mathrm{NO}_{2}^{-}$ & $\mathrm{meq} / \mathrm{L}$ & 0.00 & 0.003 & 0.00 & 0.00 & 0.00 & \\
\hline $\mathrm{SO}_{4}{ }^{2-}$ & $\mathrm{meq} / \mathrm{L}$ & 0.00 & 0.38 & 0.09 & 0.02 & 0.11 & $0-20$ \\
\hline $\mathrm{SO}_{3}{ }^{2-}$ & $\mathrm{meq} / \mathrm{L}$ & 0.00 & 0.01 & 0.00 & 0.00 & 0.00 & \\
\hline $\mathrm{Ca}^{2+}$ & $\mathrm{meq} / \mathrm{L}$ & 0.48 & 3.53 & 1.84 & 1.68 & 0.87 & $0-20$ \\
\hline $\mathrm{Cl}^{-}$ & $\mathrm{meq} / \mathrm{L}$ & 0.09 & 0.31 & 0.20 & 0.18 & 0.07 & $0-30$ \\
\hline $\mathrm{Mg}^{2+}$ & $\mathrm{meq} / \mathrm{L}$ & 0.32 & 2.28 & 1.34 & 1.29 & 0.66 & $0-5$ \\
\hline $\mathbf{K}^{+}$ & meq/L & 0.02 & 0.16 & 0.09 & 0.08 & 0.04 & $0-5$ \\
\hline $\mathrm{Na}^{+}$ & $\mathrm{meq} / \mathrm{L}$ & 0.29 & 1.46 & 0.63 & 0.58 & 0.29 & $0-40$ \\
\hline $\mathrm{HCO}_{3}^{-}$ & $\mathrm{meq} / \mathrm{L}$ & 1.44 & 5.92 & 3.60 & 3.20 & 1.53 & $0-10$ \\
\hline
\end{tabular}

Table 4 Correlation Matrix for Physicochemical Parameters

\begin{tabular}{cccccccccccc}
\hline & $\mathbf{C a}^{2+}$ & $\mathbf{M g}^{2+}$ & $\mathbf{K}^{+}$ & $\mathbf{N a}^{+}$ & $\mathbf{H C O}_{3}{ }^{-}$ & $\mathbf{S O}_{\mathbf{4}}{ }^{2-}$ & $\mathbf{S O}_{\mathbf{3}}{ }^{-}$ & $\mathbf{C l}$ & $\mathbf{T D S}$ & $\mathbf{p H}$ & $\mathbf{E C}$ \\
\hline $\mathbf{C a}^{2+}$ & 1.00 & & & & & & & & & & \\
$\mathbf{M g}^{2+}$ & $\mathbf{0 . 7 2}$ & 1.00 & & & & & & & & & \\
$\mathbf{K}^{+}$ & 0.22 & -0.25 & 1.00 & & & & & & & & \\
$\mathbf{N a}^{+}$ & 0.11 & 0.40 & -0.23 & 1.00 & & & & & & & \\
$\mathbf{H C O}^{-}$ & $\mathbf{0 . 8 6}$ & $\mathbf{0 . 9 3}$ & -0.09 & 0.48 & 1.00 & & & & & & \\
$\mathbf{S O}_{4}{ }^{-}$ & 0.26 & 0.35 & 0.22 & 0.17 & 0.31 & 1.00 & & & & & \\
$\mathbf{S O}_{3}{ }^{-}$ & 0.36 & 0.22 & 0.35 & -0.20 & 0.26 & 0.27 & 1.00 & & & & \\
$\mathbf{C l}^{-}$ & 0.33 & 0.15 & 0.09 & -0.47 & 0.03 & 0.32 & 0.08 & 1.00 & & & \\
$\mathbf{T D S}$ & $\mathbf{0 . 8 0}$ & $\mathbf{0 . 9 1}$ & -0.08 & 0.44 & $\mathbf{0 . 9 4}$ & 0.32 & 0.32 & 0.10 & 1.00 & & \\
$\mathbf{p H}$ & 0.29 & 0.41 & 0.44 & -0.11 & 0.31 & 0.16 & 0.18 & 0.30 & 0.32 & 1.00 & \\
$\mathbf{E C}$ & $\mathbf{0 . 8 0}$ & $\mathbf{0 . 9 1}$ & -0.08 & 0.44 & $\mathbf{0 . 9 4}$ & 0.32 & 0.32 & 0.10 & $\mathbf{0 . 9 9}$ & 0.32 & 1.00 \\
\hline
\end{tabular}




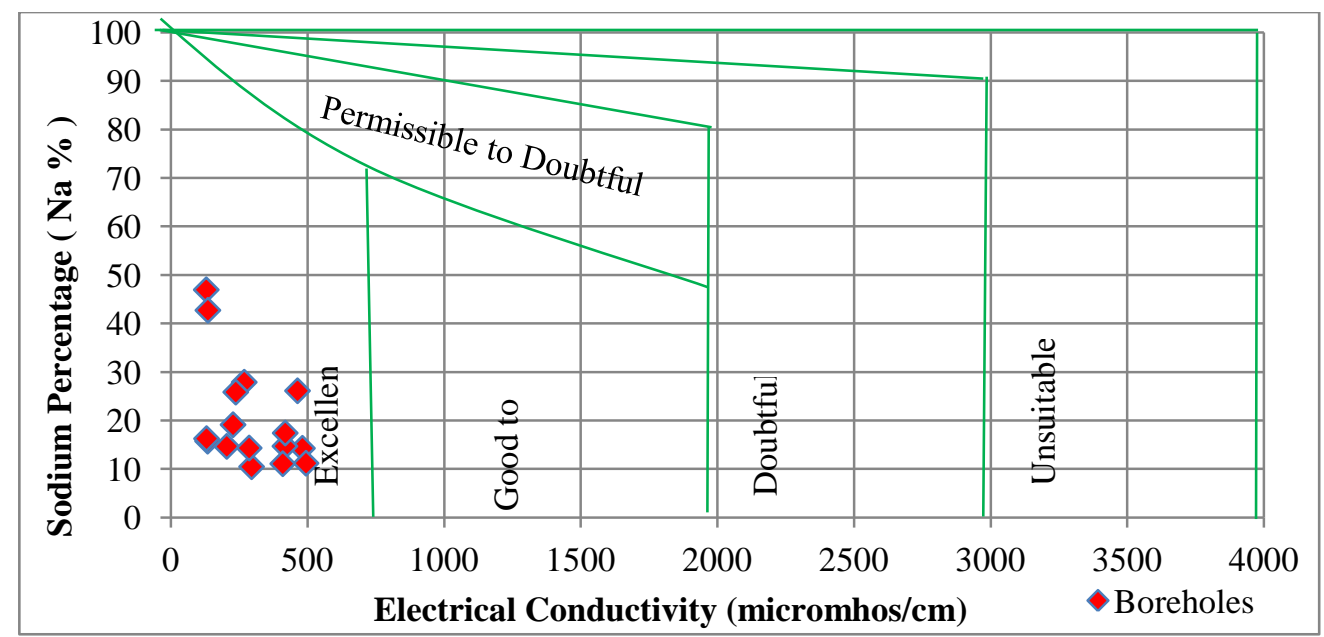

Fig. 2 Wilcox Diagram for Classification of LKD Groundwater Quality

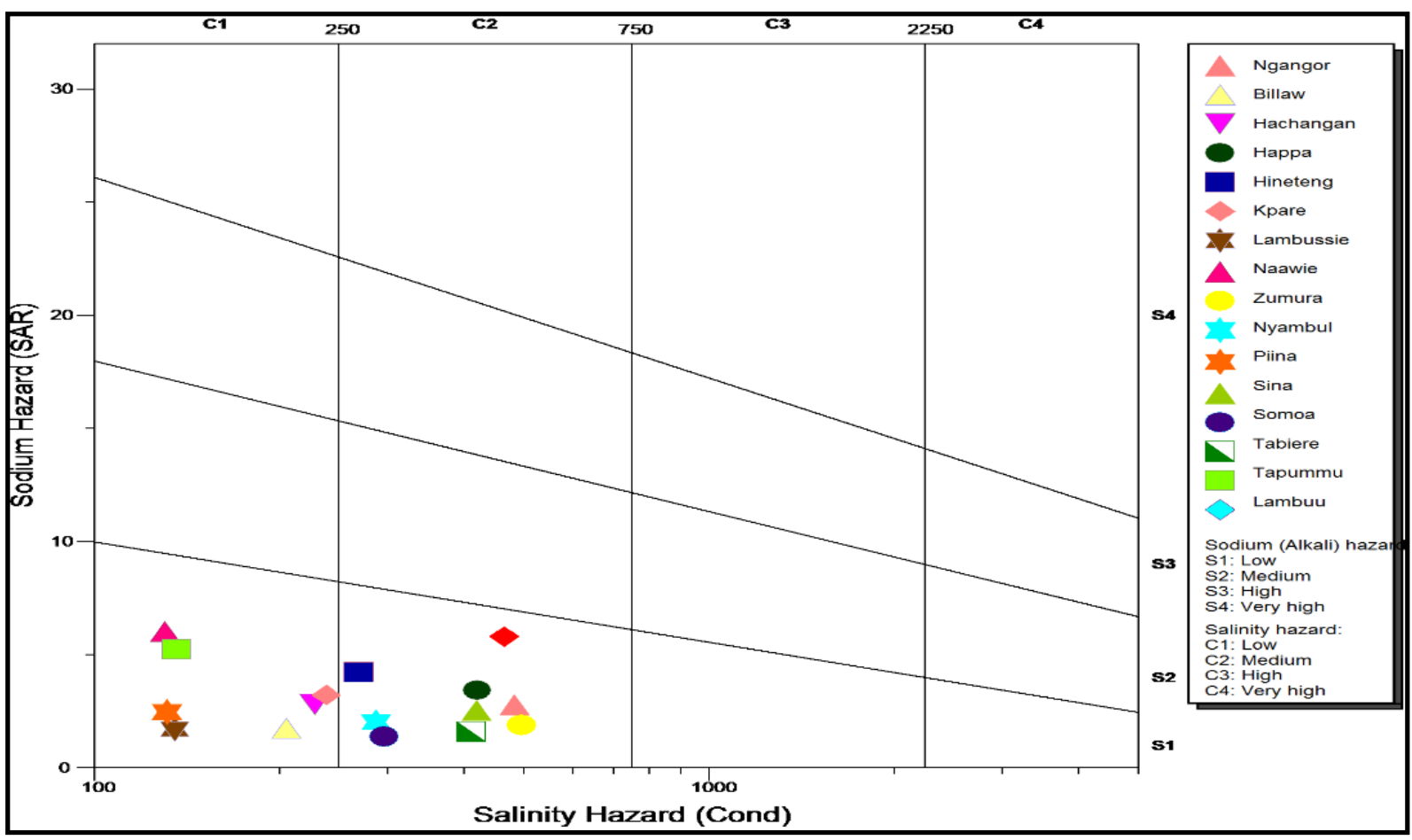

Fig. 3 US Salinity Richard Diagram of LKD Groundwater Samples

There is a strong positive correlation coefficient of $0.80,0.91,0.94$ and 0.99 between electrical conductivity and $\mathrm{Ca}^{2+}, \mathrm{Mg}^{2+}, \mathrm{HCO}_{3}{ }^{-}$and TDS respectively. Also, there exist a strong association between TDS and $\mathrm{Ca}^{2+}, \mathrm{Mg}^{2+}$ and $\mathrm{HCO}_{3^{-}}$as indicated in their positive correlation coefficient of $0.80,0.91$ and 0.94 respectively. There is a strong positive correlation of 0.72 between $\mathrm{Mg}^{2+}$ and $\mathrm{Ca}^{2+}$.

\subsection{Irrigation Water Quality Mapping}

A summary of the results of the Irrigation Water Quality (IWQ) parameters and their suitability are shown in Table 5. The spatial distribution of these IWQ parameters are shown in Fig. 4 to Fig.6.

\subsubsection{Electrical Conductivity (EC)}

EC values show a wide variation ranging from 130 to $495 \mu \mathrm{S} / \mathrm{cm}$ with a mean and standard deviation values of 296.438 and $133.868 \mu \mathrm{S} / \mathrm{cm}$ respectively. The spatial distribution and range of the various classes of EC are shown in Fig.6 and Table 5 respectively. The EC values from the study area were all less than $700 \mu \mathrm{S} / \mathrm{cm}$. This shows that groundwater is excellent for irrigation purpose according to Ayers and Westcott (1985) classification.

\subsubsection{Sodium Adsorption Ratio (SAR)}

Sodium Adsorption Ratio (SAR) ranges between 1.38 and 6.04. The spatial distribution and range of 
the various classes of SAR are shown in Fig. 4a and Table 5 respectively. From the SAR results, all the samples are within the excellent category, which translates that the groundwater is suitable for irrigation.

\subsubsection{Residual Sodium Carbonate (RSC)}

Residual sodium carbonate which is a measure of bicarbonate in the groundwater was calculated using Eaton (1950) equation. The calculated RSC values range from 0.02 to 1.73 with a mean value of 0.42 . The negative RSC values mean that more $\mathrm{Ca}$ and $\mathrm{Mg}$ ions were present in the groundwater than carbonates.

Table 5 Irrigation Water Quality Parameters

\begin{tabular}{|c|c|c|c|}
\hline Parameter & Results & Range & Water Quality Category \\
\hline \multirow{3}{*}{$\begin{array}{c}\mathbf{E C} \\
(\mu \mathrm{S} / \mathrm{cm})\end{array}$} & \multirow{3}{*}{$130-495$} & $<700$ & Excellent \\
\hline & & $700-3000$ & Good \\
\hline & & $>3000$ & Unsuitable \\
\hline \multirow{4}{*}{ SAR } & \multirow{4}{*}{$1.38-6.04$} & $<10$ & Excellent \\
\hline & & $10-18$ & Good \\
\hline & & $18-26$ & Doubtful \\
\hline & & $>26$ & Unsuitable \\
\hline \multirow{3}{*}{ RSC } & \multirow{3}{*}{$-0.02-1.731$} & $<1.25$ & Good \\
\hline & & $1.25-2.5$ & Doubtful \\
\hline & & $>2.5$ & Unsuitable \\
\hline \multirow{5}{*}{$\mathrm{Na} \%$} & \multirow{5}{*}{$10.45-46.94$} & $<20$ & Excellent \\
\hline & & $20-40$ & Good \\
\hline & & $40-60$ & Permissible \\
\hline & & $60-80$ & Doubtful \\
\hline & & $>80$ & Unsuitable \\
\hline \multirow{3}{*}{ PI } & \multirow{3}{*}{$49.34-120.08$} & $<25$ & Excellent \\
\hline & & $25-75$ & Good \\
\hline & & $>75$ & Unsuitable \\
\hline \multirow{3}{*}{ pH } & \multirow{3}{*}{$6.97-7.90$} & $7-8$ & Excellent \\
\hline & & $6.5-7$ and $8-8.5$ & Good \\
\hline & & $<6.5$ and $>8.5$ & Unsuitable \\
\hline \multirow{3}{*}{$\mathrm{HCO}_{3}^{-}$} & \multirow{3}{*}{$87.6-361$} & $<90$ & Excellent \\
\hline & & $90-500$ & Good \\
\hline & & $>500$ & Unsuitable \\
\hline
\end{tabular}
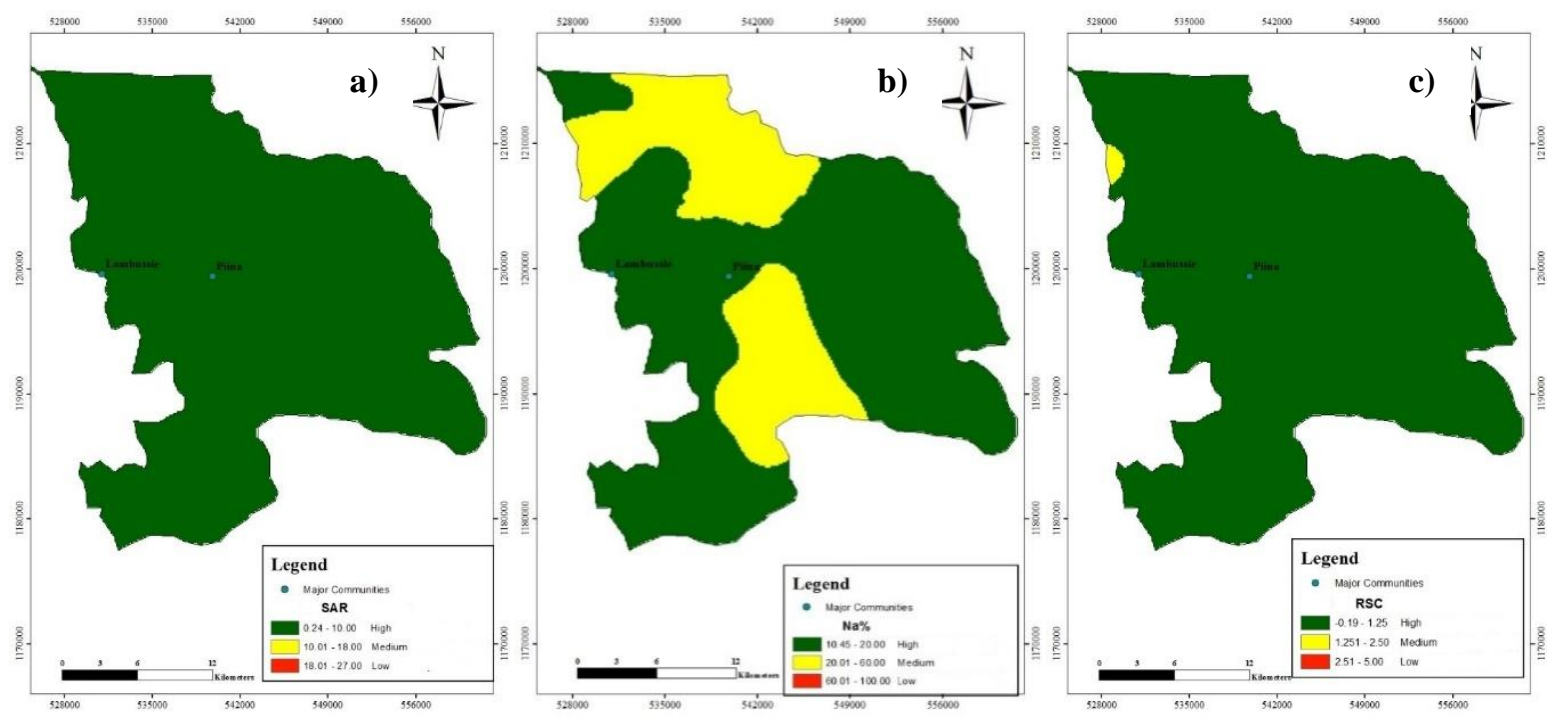

Fig. 4 Spatial Variation of Irrigation Water Quality Parameters [ a) SAR b) Na\% c) RSC 
The spatial distribution and range of the various classes of SAR are shown in Fig. $4 \mathrm{c}$ and Table 5 respectively. Within the district, $93.75 \%$ of the samples are within the good category and $6.25 \%$ of the samples were in the category of doubtful groundwater quality.

\subsubsection{Sodium Percentage ( $\mathrm{Na} \%)$}

The calculated mean value of the sodium percentage in the groundwater was $20.56 \%$ and ranged between $10.45 \%$ and $46.94 \%$. The spatial distribution and range of the various classes of $\mathrm{Na}$ $\%$ are shown in Fig. $4 \mathrm{~b}$ and Table 5 respectively.

$68.75 \%$ of the samples from the study area are in the category of excellent whilst $18.75 \%$ and 12.5
$\%$ were found to be good and permissible respectively for irrigation.

\subsubsection{Permeability Index (PI)}

Permeability index measures the permeability of the soil after irrigating a land over a long period. PI is greatly influenced by $\mathrm{HCO}_{3}^{-}, \mathrm{Na}^{+}, \mathrm{Mg}^{2+}$ and $\mathrm{Ca}^{2+}$. The PI values were computed and classified using Doneen (1964) and Raghunath (1987) methods. The spatial distribution and range of the various classes of PI are shown in Fig. 5b and Table 5 respectively. The district had $81.25 \%$ of samples in the good category whilst $18.75 \%$ of the samples were unsuitable for irrigation.
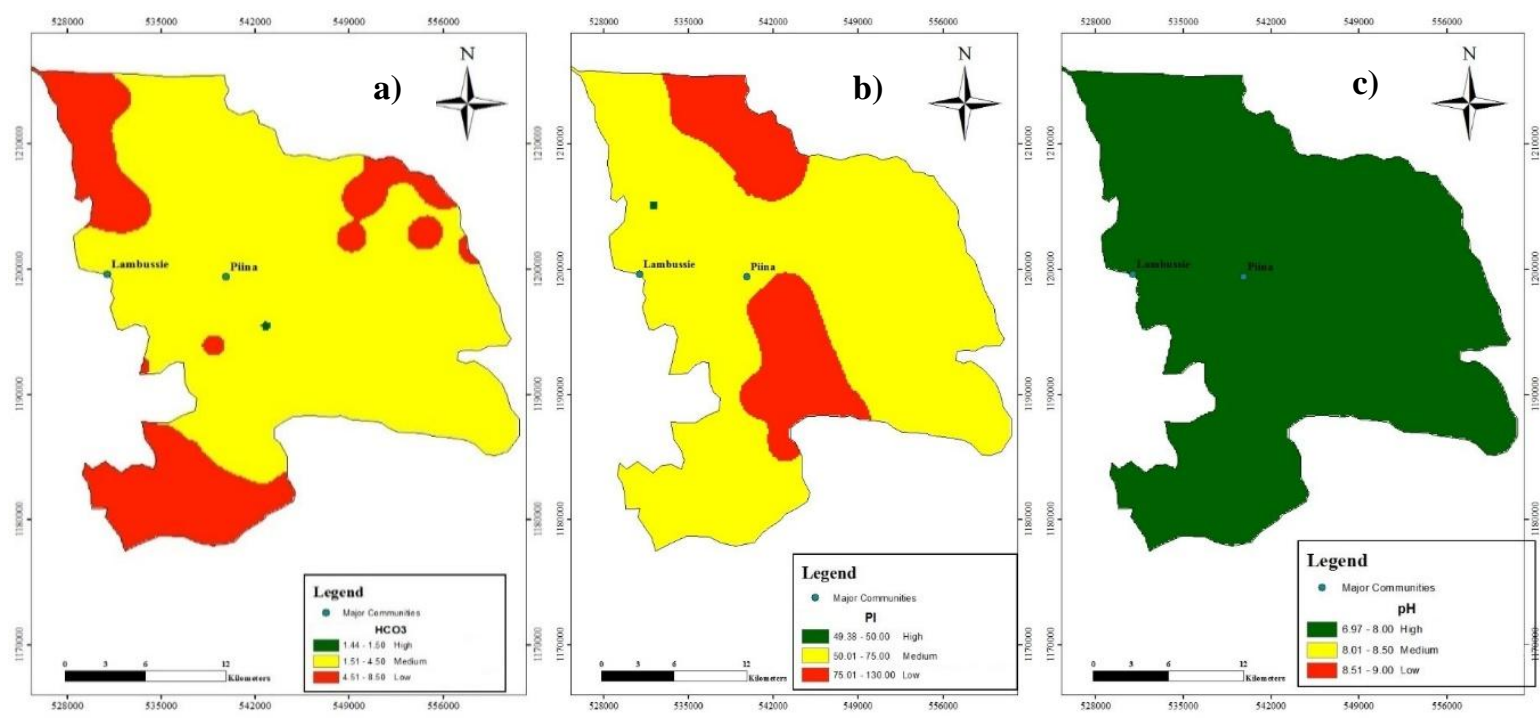

Fig.5 Spatial Variation of Irrigation Water Quality Parameters [ a) $\mathrm{HCO}_{3}^{-}$b) $\mathrm{PI}$ c) $\mathrm{pH}$

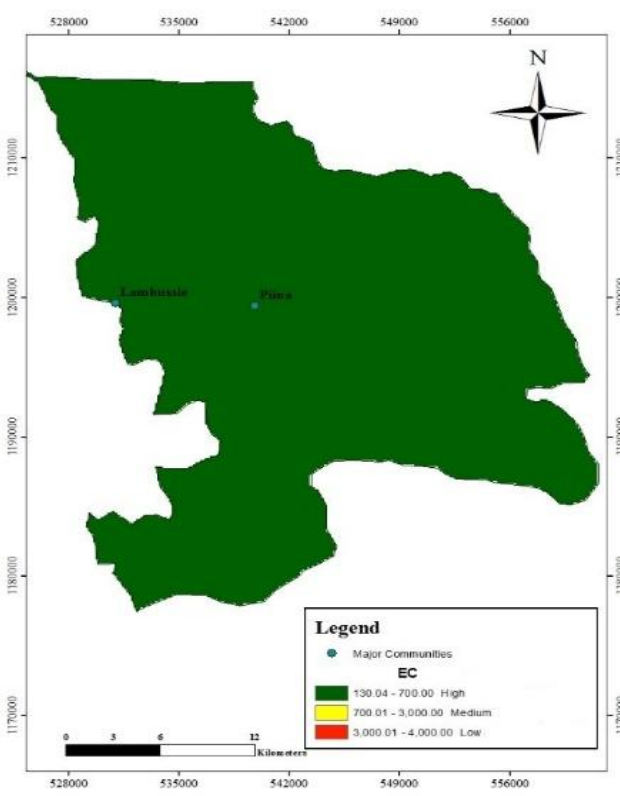

Fig. 6 Spatial Variation of Irrigation Water Quality Parameter EC

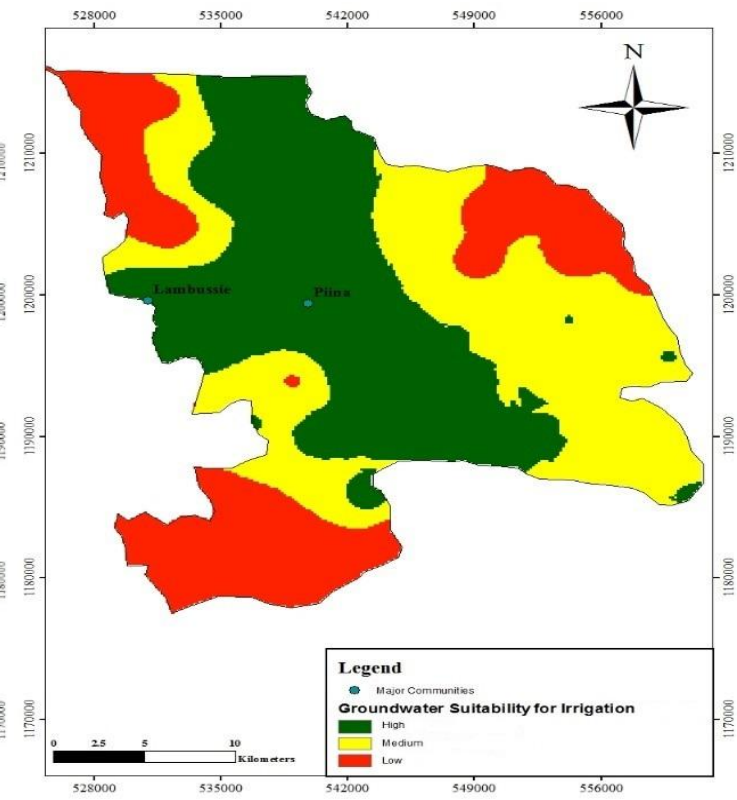

Fig. 7 Irrigation Water Quality Index Map for Lambussie-Karni District 
Table 6 Areal Extent of Groundwater Suitability for the District based on IWQI

\begin{tabular}{cccc}
\hline IWQI & Suitability for Irrigation & Area $\left.\mathbf{( k m}^{\mathbf{2}}\right)$ & Area $\mathbf{( \% )}$ \\
\hline$<22$ & Low & 199.55 & 24.58 \\
$22-37$ & Medium & 288.98 & 35.59 \\
$>37$ & High & 323.37 & 39.83 \\
\hline
\end{tabular}

\section{$3.4 .6 \mathrm{pH}$ and $\mathrm{HCO}_{3}$}

The spatial distribution and range of the various classes of $\mathrm{pH}$ are shown in Fig. $5 \mathrm{c}$ and Table 5 respectively. This indicates that the groundwater in the catchment is neutral to moderately alkaline and resulted from natural rock weathering and biogeochemical processes such as the decay of organic matter which is common in humid climates. The spatial distribution and range of the various classes of $\mathrm{HCO}_{3}{ }^{-}$are shown in Fig. 5a and Table 5 respectively.

Most of the irrigation water quality parameters namely; EC, SAR, RSC, $\mathrm{Na} \%, \mathrm{PI}, \mathrm{pH}$ and $\mathrm{HCO}_{3}{ }^{-}$ fall in the excellent to good category with very small percentage of the area in the unsuitable category.

\subsection{Irrigation Water Quality Index(IWQI) Map}

The thematic maps of the various irrigation water quality parameters were generated using the geostatistical analyst tool. These maps were reclassified into three irrigation water suitability classes as shown in Table 2. namely low (1), medium (2) and high (3). The IWQI map was finally generated by using the Map algebra tool and the result is shown in Fig. 7. The various areal extent of the groundwater suitability in the Lambussie-Karni District based on IWQI map is shown in Table 6 . About $40 \%$ of the groundwater had a high suitability for irrigation whilst about 36 $\%$ and $24 \%$ had medium and low suitability respectively.

\section{Conclusions}

Analysis of physicochemical data, deductions from standard diagrams and spatial distribution of irrigation water quality parameters were used to assess the suitability of groundwater in the Lambussie-Karni District for irrigation. Analytical data plot on the US salinity diagram (Richard diagram) shows that majority of groundwater samples fall in the field of C1S1 and C2S1; indicating low salinity and low sodium and medium salinity and low sodium water respectively.

A plot of the sodium percentage against electrical conductivity show all the samples to be within the excellent zone on the Wilcox plot. Generally, the overall groundwater quality in the catchment area is suitable for irrigation. From the IQWI map, groundwater generally is suitable for irrigation in the District except that $24.57 \%$ of the district will require crops which can tolerate high amount of salts.

\section{References}

Aghazadeh, N. and Mogaddam, A. A. (2010), "Assessment of Groundwater Quality and Its Suitability for Drinking and Agricultural Uses in the Oshnavieh Area, Northwest of Iran", Journal of Environmental Protection, 1(01), pp. 30.

Anku, Y. S., Banoeng-Yakubo, B., Asiedu, D. K. and Yidana, S. M. (2009), "Water Quality Analysis of Groundwater in Crystalline Basement Rocks, Northern Ghana”, Environmental Geology, 58(5), pp. 989-997.

Anon. (2014), "2010 Population and Housing Census, District analytical Report", Ghana Statistical Report, Lambussie-Karni District, 89 pp.

Ayers, R. S. and Westcot, D. W. (1989). "Salinity problems", Water quality for agriculture. FAO, Rome, Italy, 1-32.

Ayers, R.S. and Westcot, D.W. (1985), "Water Quality for Agriculture", Irrigation and drainage, Paper No. 29, Food and Agriculture Organization of the United Nations, Rome, Italy, 174 pp.

Barcelona, M. J., Gibb.P. M., Helfrick, A.J. and Garske, E.E. (1985), "Practical Guide for Ground-Water Sampling”, Illinois State Water Survey, Vol. 374, Contract Report 374, 75 pp.

Dickson, K. B. and Benneh, G. (1988), A New Geography of Ghana, UK, Longman Group Limited, $170 \mathrm{pp}$.

Doneen, L. D. (1964), "Notes on Water Quality in Agriculture", Department of Water Science and Engineering, University of California, Water Science and Engineering, 400 pp.

Dzigbodi-Adjimah, K. (1993), "Geology and Geochemical Patterns of the Birimian Gold Deposits, Ghana, West Africa", Journal of Geochemical Exploration, 47(1-3), pp. 305-320.

Eaton, F. M. (1950), "Significance of Carbonates in Irrigation Waters", Soil Science, 69(2), pp. 123134, and Environment, 49, pp. 761-784. 
Fipps, G. (2003), “Irrigation Water Quality Standards and Salinity Management Strategies", Texas Farmer Collection, pp. 1-19.

Gale, I. N. and Robins, N. S. (1989), "The Sampling and Monitoring of Groundwater Quality", British Geological Survey, Hydrogeology Report, (89/37).

Jasmin, I. and Mallikarjuna, P. (2015), "Evaluation of Groundwater Suitability for Irrigation in the Araniar River Basin, South India-A Case Study Using GIS Approach", Irrig. and Drain., Vol. 64, No. 5, pp. 600-608.

Khalaf, R.M. and Hassan, W.H. (2013), "Evaluation of Irrigation Water Quality Index (IWQI) for Al-Dammam Confined Aquifer in the West and Southwest of Karbala City, Iraq", International Journal of Civil Engineering, Vol. 23, pp. 21-34.

Little, J., Kalischuk, A., Gross, D. and Sheedy, C. (2010), "Assessment of water quality in Alberta's irrigation districts" Alberta Agriculture and Rural Development, Alberta, Canada.

Quist, L. G., Bannerman, R. R. and Owusu, S. (1988), "Groundwater in Rural Water Supply in Ghana", Report of the West African SubRegional Workshop, Accra, Ghana, pp. 20-24.

Raghunath, H. M. (1987), Groundwater, 2nd Edition. Wiley, New Delhi, pp. 344-369.

Richards. L. M. (1954), "Diagnosis and Improvement of Saline and Alkaline Soils", Agriculture Handbook, No. 60, US Salinity Laboratory, USDA, 160 pp.

Rokbani, M.K., Gueddari N., and Bouhlila, R. (2011), "Use of Geographical Information System and Water Quality Index to Assess Groundwater Quality in El Khairat Deep Aquifer (Enfidha, Tunisian Sahel)", Iranica Journal of Energy and Environment Vol. (2), No.2, pp. 133-144.

Roudakov, V.M. (1991), "Report on the geology and minerals of the north-western part of the Wa field sheet" Ghana Geological Survey Archive, Report 50, pp. 95.

Salifu, M., Aidoo, F., Hayford, M. S., Adomako, D. and Asare, E. (2015), "Evaluating the Suitability of Groundwater for Irrigational Purposes in Some Selected Districts of the Upper West Region of Ghana", Applied Water Science, pp. 1-10.

Simsek, C. and Gunduz, O. (2007), "IWQ index: A GIS integrated technique to assess irrigation water quality", Environmental Monitoring and Assessment, Vol. (128), pp. 277-300.

Wilcox, L. V. (1948), “The Quality of Water for Irrigation Use", US Dept. of Agricultural Technology Bulleton, 1962, Washington DC, pp. 1-40.

Wilcox, L. V. (1955), "Classification and Use of Irrigation Waters", US Department of Agriculture, Washington, DC, Circular, No. 969, 1047 pp.
Authors

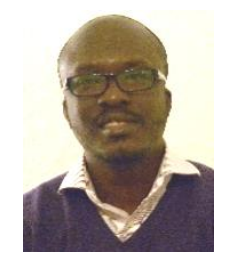

Dr Asare Asante-Annor is a lecturer at the Geological Engineering Department at the University of Mines and Technology, Tarkwa. He holds a BSc (Hons) in Geological Engineering from the Kwame Nkrumah University of Science and Technology, KNUST, Kumasi, Ghana. He also holds an MSc in Environmental Resources Management and a $\mathrm{PhD}$ in Environmental Engineering from Brandenburg Technical University, Cottbus, Germany. His areas of research interest include water resources management and regulations, geochemistry of groundwater resources and waste management. $\mathrm{He}$ is a member of the International Association of Hydrogeologists.

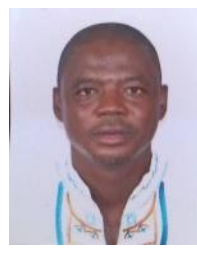

Philip Nerry Bewil has successfully defended His MSc. Thesis in Geological Engineering and holds BSc. Geological Engineering from University of Mines and Technology (UMaT), Ghana. $\mathrm{He}$ has experience in Mineral Exploration in Ghana, Nigeria and Guyana as well as Groundwater Exploration in Northern Ghana.

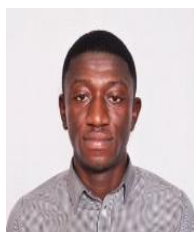

Dennis Boateng is a $\mathrm{PhD}$ candidate in the Hydrology Laboratory at Kumamoto University, Japan. He holds an MSc Geological Engineering degree from the University of Mines and Technology, Tarkwa, Ghana and a BSc Petroleum Engineering degree from Kwame Nkrumah University of Science and Technology, Ghana. His current research is on using isotopic tracers and soil properties to clarify infiltration mechanism through the unsaturated zone as well as deduce associated nitrate transformation processes occurring through the zone. 